\title{
Performance of Sugarcane Varieties with Respect of Growth Parameters and their Management in Sodic Soil
}

\author{
S Manjula, A Vadivel and M Jayalakshmi* \\ Depertment of Soil Science, \\ Tamil Nadu Agricultural University, Coimbatore - 641 003, Tamil Nadu, India \\ *Central Research Institute for Dryland Agriculture, Hyderabad - 500 059, Andhra Pradesh, India \\ e-mail: jayalakshmimitnala@gmail.com
}

Received: 06 May 2014; Revised accepted: 15 January 2015

\begin{abstract}
A B S T R A C T
A field experiment on sugarcane was conducted at Anbil Dharmalingam Agricultural College and Research Institute, Tiruchirapalli with the view to identify sodic tolerant variety and suitable amendment for sodic soil. Four sugarcane varieties viz Co Si (Sc) 6, Co C (Sc) 86032, Co C (Sc) 23 and Co G (Sc) 5 and three amendments viz pressmud @ $12.5 \mathrm{t} \mathrm{ha}^{-1}$, gypsum @ $4.8 \mathrm{t} \mathrm{ha}^{-1}$ and bottom slag @ $15 \mathrm{t} \mathrm{ha}^{-1}$ were studied along with the unamended control in the experiment were studied. The experiment was conducted in a factorial randomized block design with three replications. The observations on germination percentage, tillers, plant height, leaf area index, number of internodes, internodal length, cane length, cane girth, single cane weight and number of millable canes, were recorded. The results revealed that sugarcane varieties Co G (Sc) 5 and Co C (Sc) 23 gave better growth characters as compared to the Co Si (Sc) 6 and Co C (Sc) 86032 under sodic soil. The sugarcane varieties namely Co G (Sc) 5 and $\mathrm{Co} C(\mathrm{Sc}) 23$ were found to be superior in respect of both germination percentage and number of millable canes, hence these might be considered suitable for growing under sodic soil.
\end{abstract}

Key words: Sodic soil, Growth parameters, Sugarcane varieties, Tiller count

In India there are about 7.0 million hectares of salt effected soils, of which 2.80 million hectares (Abrol and Bhumbla 1971) are sodic in nature. In Tamil Nadu out of 4.7 lakh ha of salt affected soils 3.0 lakh ha are sodic (Mahamood-Haroon et al. 1996). These soils are characterized by high $\mathrm{pH}(>8.5)$ and ESP level between 15 and 90. Salt affected soils are known to have serious effects on crop growth, nutrient uptake and yield in several crops due to the presence of excessive amount of soluble salts and exchangeable sodium. Though sugarcane is known to be semi-tolerant to soil sodicity and moderately sensitive to salinity, the yield reductions ranging from 10 to 50 percent due to sodicity have been reported. Adverse effects of sodicity can be minimized and productivity can be improved significantly by adopting suitable varieties and management practices. The improvement and reclamation of these soils is very expensive and resources are limited. Hence, the selection and breeding varieties for salt tolerance is the long term solution to the sodicity problem (Ashraf et al. 1986, Epstein and Rains 1987). The present investigation was undertaken to select or screen the sugarcane varieties for sodicity tolerance under sodic soil conditions.

\section{MATERIALS AND METHODS}

A field experiment on sugarcane was conducted at Anbil Dharmalingam Agricultural College and Research Institute, Tiruchirapalli with the view to identify sodic tolerant variety and suitable amendment for sodic soil. Four sugarcane varieties viz Co $\mathrm{Si}(\mathrm{Sc}) 6, \mathrm{Co} \mathrm{C}(\mathrm{Sc}) 86032$, Co C (Sc) 23 and $\mathrm{Co} G(\mathrm{Sc}) 5$. The experimental soil was sandy loam in texture, belonging to Adavathur soil series, taxonomically termed as Vertic Ustropepts. The soil was alkaline in reaction with $\mathrm{pH} 8.76$ and $\mathrm{EC}$ of $0.32 \mathrm{dS} \mathrm{m}^{-1}$ and was low in available nitrogen $\left(224 \mathrm{~kg} \mathrm{ha}^{-1}\right)$, medium in available phosphorus and potassium $\left(12.6,210 \mathrm{~kg} \mathrm{ha}^{-1}\right.$ respectively). The organic carbon content of the soil is medium with 0.65 percent. The exchangeable sodium percentage and cation exchange

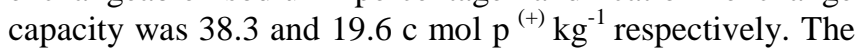
observations on germination percentage (30 DAP), tillers (90 DAP), plant height, leaf area index, number of internodes, internodal length, cane length, cane girth, single cane weight and number of millable canes, at harvest were recorded.

\section{RESULTS AND DISCUSSION}

Germination percent 
The mean germination percentage differed significantly among varieties. The variety $\mathrm{Co} G(\mathrm{Sc}) 5\left(\mathrm{~V}_{4}\right)$ recorded the higher germination count of 62.6 percent followed by Co C (sc) $23\left(\mathrm{~V}_{3}\right)(41.1 \%)$ and the poorest performances were by Co $\mathrm{Si}(\mathrm{Sc}) 6\left(\mathrm{~V}_{1}\right)(23.5 \%)$ and $\mathrm{Co} \mathrm{C}(\mathrm{Sc}) 86032\left(\mathrm{~V}_{2}\right)$ (23.9\%) which were on par (Table 1). However there was no significant difference observed in germination percent among amendments.

Table 1 Performance of varieties and effect of amendments on germination $(\%)$ of sugarcane

\begin{tabular}{|c|c|c|c|c|c|}
\hline Treatments & $\mathrm{V}_{1}$ & $\mathrm{~V}_{2}$ & $\mathrm{~V}_{3}$ & $\mathrm{~V}_{4}$ & Mean \\
\hline $\mathrm{T}_{1}$ & 19.9 & 18.4 & 37.8 & 58.3 & 33.6 \\
\hline $\mathrm{T}_{2}$ & 24.0 & 25.2 & 41.0 & 61.8 & 38.0 \\
\hline $\mathrm{T}_{3}$ & 26.6 & 26.9 & 45.3 & 63.7 & 40.6 \\
\hline $\mathrm{T}_{4}$ & 23.7 & 25.1 & 40.2 & 66.5 & 38.8 \\
\hline Mean & 23.5 & 23.9 & 41.1 & 62.6 & 37.8 \\
\hline \multirow{2}{*}{\multicolumn{2}{|c|}{ V }} & \multicolumn{2}{|c|}{ SE d } & \multicolumn{2}{|c|}{ CD (0.05) } \\
\hline & & \multicolumn{2}{|c|}{3.5} & \multicolumn{2}{|c|}{7.1} \\
\hline \multicolumn{2}{|c|}{$\mathrm{T}$} & \multicolumn{2}{|c|}{3.5} & \multicolumn{2}{|c|}{ NS } \\
\hline \multicolumn{2}{|c|}{$\mathrm{V} \times \mathrm{T}$} & \multicolumn{2}{|c|}{7.0} & \multicolumn{2}{|c|}{ NS } \\
\hline
\end{tabular}

Tiller count

The tiller numbers ranged from 6.66 to 12.33 . Varieties had significant effect on tiller count (Table 2). Among the varieties $\mathrm{Co} G(\mathrm{Sc}) 5\left(\mathrm{~V}_{4}\right)$ recorded the higher tiller count of 10.25 plant $^{-1}$ which was on par with $\mathrm{V}_{3}(9.50 \%)$. However, amendments failed to establish significant differences in tiller count.

Table 2 Performance of varieties and effect of amendments on tiller count of sugarcane

\begin{tabular}{|c|c|c|c|c|c|}
\hline Treatments & $\mathrm{V}_{1}$ & $\mathrm{~V}_{2}$ & $\mathrm{~V}_{3}$ & $V_{4}$ & Mean \\
\hline $\mathrm{T}_{1}$ & 6.66 & 7.66 & 7.33 & 9.33 & 7.75 \\
\hline $\mathrm{T}_{2}$ & 7.66 & 8.33 & 8.33 & 9.33 & 8.41 \\
\hline $\mathrm{T}_{3}$ & 8.00 & 8.00 & 12.33 & 11.00 & 9.83 \\
\hline $\mathrm{T}_{4}$ & 6.67 & 9.66 & 10.00 & 11.33 & 9.41 \\
\hline Mean & 7.25 & 8.41 & 9.50 & 10.25 & 8.85 \\
\hline \multirow{2}{*}{\multicolumn{2}{|c|}{ V }} & \multicolumn{2}{|c|}{ SE d } & \multicolumn{2}{|c|}{ CD (0.05) } \\
\hline & & \multicolumn{2}{|c|}{0.92} & \multicolumn{2}{|c|}{1.89} \\
\hline \multicolumn{2}{|c|}{$\mathrm{T}$} & \multicolumn{2}{|c|}{0.92} & \multicolumn{2}{|c|}{ NS } \\
\hline \multicolumn{2}{|c|}{$V \times T$} & \multicolumn{2}{|c|}{1.85} & \multicolumn{2}{|c|}{ NS } \\
\hline
\end{tabular}

Plant height

The mean shoot heights recorded on 60, 90,120,150 and 180 DAP are presented in (Table 3 ). On $60^{\text {th }}$ DAP there was significant difference was observed in plant height among varieties. The variety $\mathrm{Co} G(\mathrm{Sc}) 5\left(\mathrm{~V}_{4}\right)$ recorded higher plant height of $101 \mathrm{~cm}$ which was on par with $\mathrm{V}_{3}(97 \mathrm{~cm})$. Among the amendments, application of gypsum @ $4.8 \mathrm{t} \mathrm{ha}^{-1}$ recorded higher plant height of $97 \mathrm{~cm}$, which was on par with $\mathrm{T}_{4}(96 \mathrm{~cm})$ and $\mathrm{T}_{2}(90 \mathrm{~cm})$. The interaction effect had no significant effect on plant height. At 90 DAP, varieties showed significant difference on plant height. The variety Co $\mathrm{G}(\mathrm{Sc}) 5\left(\mathrm{~V}_{4}\right)$ recorded higher plant height of $149 \mathrm{~cm}$ than other varieties. Amendments and interaction effect failed to register significant difference with respect to plant height. At 120 DAP, the varieties showed significant differences in plant height. Among the amendments, application of gypsum @ $4.8 \mathrm{t} \mathrm{ha}^{-1}\left(\mathrm{~T}_{3}\right)$ recorded higher plant height of $224 \mathrm{~cm}$ which was on par with $\mathrm{T}_{4}(223 \mathrm{~cm})$ and $\mathrm{T}_{2}(215 \mathrm{~cm})$. The interaction had no significant effect on plant height. At 150 DAP, the plant height ranged from 198 to $287 \mathrm{~cm}$. Among the varieties $\mathrm{Co} G(\mathrm{Sc}) 5\left(\mathrm{~V}_{4}\right)$ recorded higher plant height of $275 \mathrm{~cm}$. Application of gypsum @ $4.8 \mathrm{t} \mathrm{ha}^{-1}\left(\mathrm{~T}_{3}\right)$ recorded higher plant height of $285 \mathrm{~cm}$ which was on par with $\mathrm{T}_{4}$ $(276 \mathrm{~cm})$. At 180 DAP, the plant height ranged from 294 to $355 \mathrm{~cm}$ but no significant differences due to varieties and interaction effect were noticed. Among the amendments, application of gypsum @ $4.8 \mathrm{t} \mathrm{ha}^{-1}\left(\mathrm{~T}_{3}\right)$ recorded higher plant height of $335 \mathrm{~cm}$.

\section{Leaf area index (LAI)}

The Leaf Area Index (LAI) ranged from 3.37 to 3.96 among the varieties and from 3.64 to 3.92 among amendments. The variety $\mathrm{V}_{4}$ showed the higher LAI (3.96) than the others (Table 4). Among the treatments $\mathrm{T}_{3}$ registered numerically higher LAI of 3.92 though amendments failed to attain significant difference. Interaction effect had no significant difference on leaf area index.

\section{Number of internodes}

The performance of varieties and effect of amendments on number of internodes significantly varied. Internodes were found to range from 13.0 to 22.6. Among the varieties, $\mathrm{V}_{4}$ recorded higher number of internodes (20.0) followed by $\mathrm{V}_{3}$ (18.6) and $\mathrm{V}_{2}$ (17.8). Application of gypsum @ $4.8 \mathrm{t} \mathrm{ha}^{-1}$ recorded higher number of internodes (20.8) followed by bottomslag@15 t ha ${ }^{-1}$ (19.7). The interaction effect was also found to be significant and the best combination was $\mathrm{T}_{3} \mathrm{~V}_{4}$ (22.6).

Table 3 Performance of varieties and effect of amendments on plant height $(\mathrm{cm})$ of sugarcane

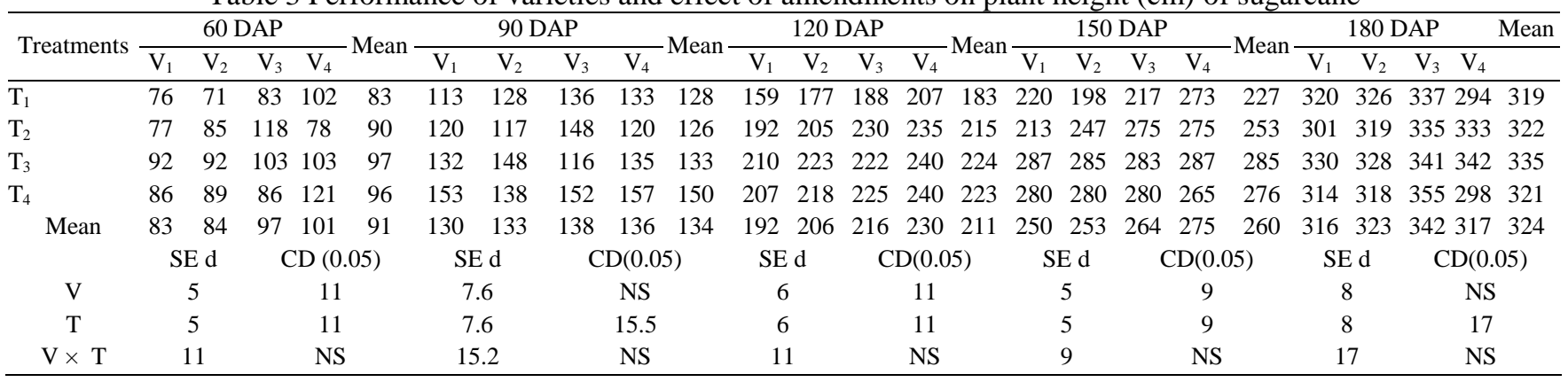




\section{Growth Parameters and their Management in Sodic Soil}

Table 4 Performance of varieties and effect of amendments on leaf area index (LAI) of sugarcane at $180 \mathrm{DAP}$

\begin{tabular}{cccccc}
\hline Treatments & $\mathrm{V}_{1}$ & $\mathrm{~V}_{2}$ & $\mathrm{~V}_{3}$ & $\mathrm{~V}_{4}$ & Mean \\
\hline $\mathrm{T}_{1}$ & 3.36 & 3.63 & 3.38 & 3.92 & 3.57 \\
$\mathrm{~T}_{2}$ & 3.50 & 3.64 & 3.33 & 4.11 & 3.64 \\
$\mathrm{~T}_{3}$ & 3.13 & 4.19 & 4.14 & 4.24 & 3.92 \\
$\mathrm{~T}_{4}$ & 3.50 & 3.24 & 4.24 & 3.58 & 3.64 \\
Mean & 3.37 & 3.67 & 3.77 & 3.96 & 3.69 \\
& \multicolumn{4}{c}{ SE d } & CD $(0.05)$ \\
\multicolumn{4}{c}{$\mathrm{V}$} & & \multicolumn{2}{c}{0.16} & \multicolumn{2}{c}{0.32} \\
$\mathrm{~T}$ & & \multicolumn{2}{c}{0.16} & \multicolumn{2}{c}{$\mathrm{NS}$} \\
\multicolumn{2}{c}{$\mathrm{V} \times \mathrm{T}$} & & 0.32 & & 0.65 \\
\hline
\end{tabular}

Internodal length

Varietal performance on internodal length showed significant variation from 7.32 to $8.74 \mathrm{~cm}$. The highest internodal length was recorded in $\mathrm{V}_{4}(8.74 \mathrm{~cm})$ followed by $\mathrm{V}_{3}(7.93 \mathrm{~cm})$ and $\mathrm{V}_{2}(7.80 \mathrm{~cm})$. Among the amendments application of gypsum @ $4.8 \mathrm{t} \mathrm{ha}^{-1}$ recorded higher internodal length $(8.20 \mathrm{~cm})$ followed by $\mathrm{T}_{4}(8.07 \mathrm{~cm})$ and $\mathrm{T}_{2}(7.91 \mathrm{~cm})$. The interaction effect was found to be significant. The combination of $\mathrm{T}_{3} \mathrm{~V}_{4}$ recorded higher internodal length $(9.06 \mathrm{~cm})$ and poorer performance was found in $\mathrm{T}_{1} \mathrm{~V}_{1}(6.96 \mathrm{~cm})$.

\section{Cane length}

The results on cane length showed significant variation due to varieties and amendments. Cane length ranged from 196 to $263 \mathrm{~cm}$ for genotypes, and 221 to 256 for amendments. The highest cane length of $263 \mathrm{~cm}$ was recorded by $\mathrm{V}_{4}$ followed by $\mathrm{V}_{3}(246 \mathrm{~cm})$ and $\mathrm{V}_{2}(241 \mathrm{~cm})$. Among the amendments, application of gypsum @ $4.8 \mathrm{tha}^{-1}$ $\left(\mathrm{T}_{3}\right)$ recorded higher cane length of $256 \mathrm{~cm}$ followed by $\mathrm{T}_{2}$ $(245 \mathrm{~cm})$. The interaction also had significant effect on cane length. The highest cane length was found in $\mathrm{T}_{2} \mathrm{~V}_{4}(303 \mathrm{~cm})$ followed by $\mathrm{T}_{3} \mathrm{~V}_{3}(292 \mathrm{~cm})$.

\section{Cane girth}

The cane girth varied significantly among the varieties and amendments. It ranged from 20.1 to $26.7 \mathrm{~mm}$ within the varieties and 16.7 to $26.2 \mathrm{~mm}$ within the amendments. The higher cane girth was recorded in $\mathrm{V}_{4}(26.7 \mathrm{~mm})$ followed by $\mathrm{V}_{3}(22.9 \mathrm{~mm})$ and $\mathrm{V}_{2}(23.2 \mathrm{~mm})$, which were on par. Among the amendments $\mathrm{T}_{3}$ recorded the highest cane girth of $26.2 \mathrm{~mm}$ followed by $\mathrm{T}_{4}(25.3 \mathrm{~mm})$ and $\mathrm{T}_{2}(24.7 \mathrm{~mm})$ which were on par with each other. Under different treatment combinations, the highest cane girth of $30.9 \mathrm{~mm}$ was found in $\mathrm{T}_{3} \mathrm{~V}_{4}$ and the least was in $\mathrm{T}_{1} \mathrm{~V}_{1}(12.0 \mathrm{~mm})$.

\section{Single cane weight}

A perusal of the data indicated that the varieties and amendments had significant effect on single cane weight. It ranged from 0.48 to $0.86 \mathrm{~kg}$ per cane among the varieties. Among the amendments it varied from 0.65 to $0.81 \mathrm{~kg}$ per cane. The variety $\mathrm{V}_{4}$ recorded the highest single cane weight of $0.86 \mathrm{~kg}$ per cane. $\mathrm{T}_{3}$ recorded the higher single cane weight $\left(0.81 \mathrm{~kg}\right.$ per cane) followed by $\mathrm{T}_{4}(0.78 \mathrm{~kg}$ per cane $)$. Interaction effect was also found to be significant. The treatment $\mathrm{T}_{2} \mathrm{~V}_{2}$ recorded the highest cane weight $(0.99 \mathrm{~kg}$ per cane) while the least $\left(0.32 \mathrm{~kg}\right.$ per cane) was with $\mathrm{T}_{2} \mathrm{~V}_{1}$.

Table 5 Performance of varieties and effect of amendments on growth parameters of sugarcane

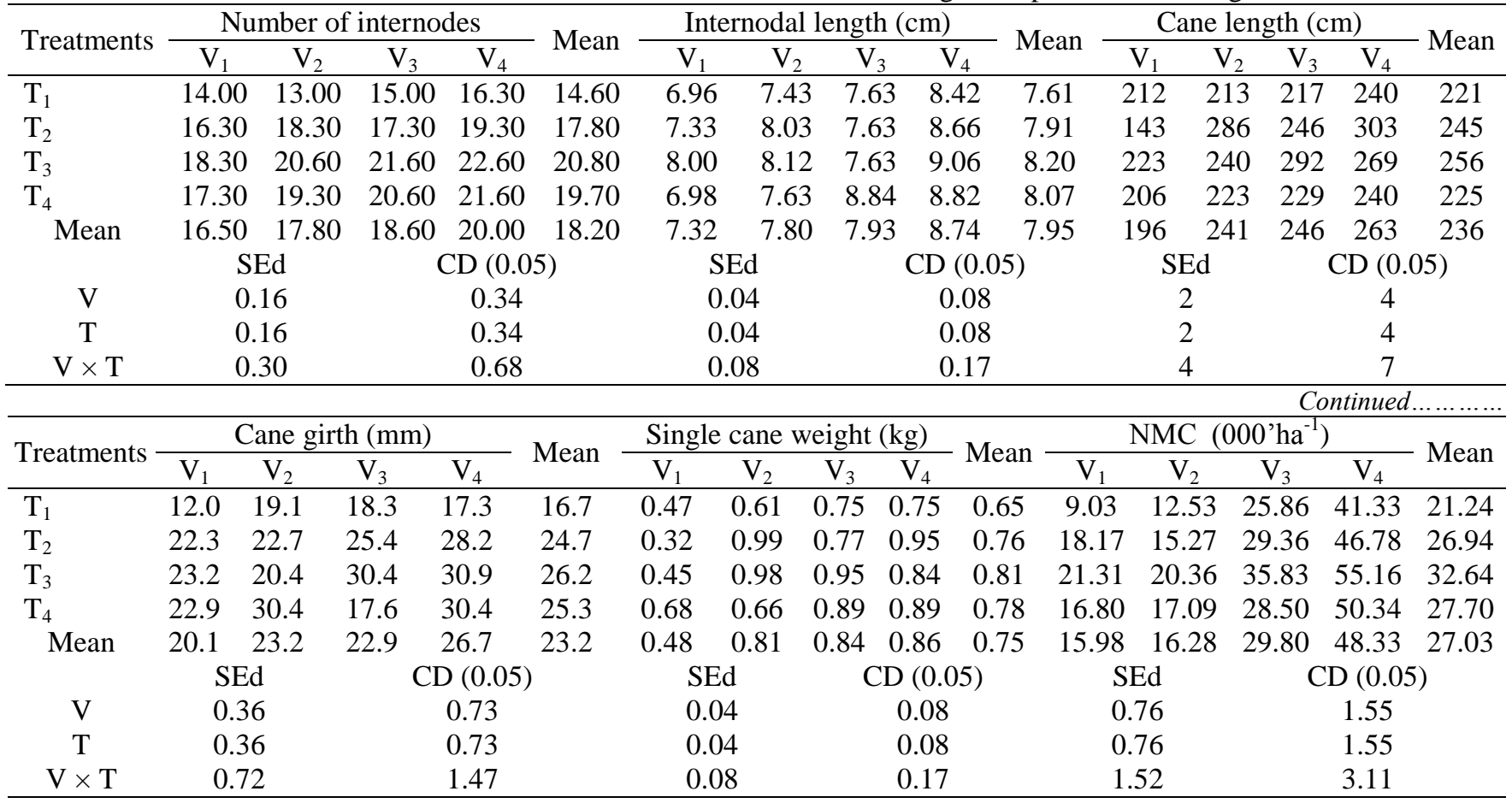

Number of millable canes

The number of millable canes differed significantly between varieties and amendments. It ranged from 15,980 to
48,330 and 21,240 to 32,640 canes ha $^{-1}$ in varieties and amendments, respectively. The variety $\mathrm{V}_{4}$ recorded the highest number of millable canes 48,330 canes $^{-1}{ }^{-1}$ followed 
by $\mathrm{V}_{3}\left(29,800\right.$ canes $\left.\mathrm{ha}^{-1}\right)$. While the lowest millable canes were recorded by $\mathrm{V}_{1}\left(15,980\right.$ canes ha $\left.{ }^{-1}\right)$ and $\mathrm{V}_{2}(16,280$ canes ha$\left.{ }^{1}\right)$ which were on par. The treatment $T_{3}\left(32,640\right.$ canes ha $\left.{ }^{-1}\right)$ recorded the maximum number of millable canes followed by $\mathrm{T}_{4}\left(27,700\right.$ canes $\left.\mathrm{ha}^{-1}\right)$ and $\mathrm{T}_{2}\left(26,940\right.$ canes ha $\left.{ }^{-1}\right)$. Significant interaction was found to exist between the amendments and varieties. The highest value $\left(55,160\right.$ canes $\left.^{-1}{ }^{-1}\right)$ was observed in the combination of $\mathrm{T}_{3} \mathrm{~V}_{3}$ and the least in $\left(9,030\right.$ canes ha $\left.{ }^{-1}\right) \mathrm{T}_{1} \mathrm{~V}_{1}$.

The performances of varieties tried under sodic conditions differed significantly with respect to growth characters. The variety $\mathrm{Co} \mathrm{G} \mathrm{(Sc)} 5$ was found to be tolerant to sodicity of soil than other varieties. The growth characters viz germination per cent, tiller count, plant height and LAI were higher with the variety $\mathrm{Co} G(\mathrm{Sc}) 5$ by registering 62.6 percent, 10.25 tillers per plant, $324 \mathrm{~cm}$ (at $180 \mathrm{DAP}$ ) and 3.96 respectively. Co $\mathrm{C}(\mathrm{Sc}) 23$ was found to be next to Co $\mathrm{G}$ (Sc) 5 in terms of germination percent, tiller count, plant height and LAI. The performance of other two varieties namely $\mathrm{Co} \mathrm{Si}(\mathrm{Sc}) 6$ and $\mathrm{Co} \mathrm{C}(\mathrm{Sc}) 86032$ were poor in terms of growth characteristics. They registered very low germination per cent, low tiller count, plant height and LAI. The variations in performance of varieties under sodic conditions might be possible due to the existence of considerable genotypic differences (Geetha et al. 2000). Similar variations in the performance of different varieties under sodic conditions were also reported by Kumaraswamy (1989) on germination, Muniaswamy (1998) on tiller count, Akthar et al. (2001) on plant height and Gomathi and Dhandapani (2005) on leaf area index. The effect of amendments on growth characters was found to be non significant. However, amended plots recorded numerically higher values of germination percent, tiller count, plant height and LAI than unamended plot. The results of growth parameters viz number of internodes, internodal length, cane length, cane girth, single cane weight and number of millable canes revealed that there were significant differences on growth parameters due to varieties and amendments tried. Co Si (Sc) 6 and Co C (Sc) 86032 were performed poorly Irrespective of growth parameters than other two varieties. Co $\mathrm{G}(\mathrm{Sc}) 5$ was found to be superior in withstanding the sodicity by registering better growth parameters than others. Similar results in sugarcane under sodic soil condition were reported by Tiwari et al. (2006). All three amendments viz gypsum, bottom slag, and press mud were registered significantly higher values of growth parameters than unamended control. While gypsum application observed to be better than two other amendments by registering significantly higher values with respect of growth parameters. It might be due to favorable soil environment (low $\mathrm{pH}$ and high calcium) created by gypsum for the growth of sugarcane under sodic condition. The reduction in values of growth parameters under sodic conditions were also observed by Robinson and Worker (1965), Gosnell (1972), Reddy (1980).

On the basis of overall varietal performance in respect of germination and number of millable canes, the varieties Co $\mathrm{C}(\mathrm{Sc}) 23$ and $\mathrm{Co} \mathrm{G}(\mathrm{Sc}) 5$ were found superior over the Co Si (Sc) 6, Co C (Sc) 86032 and may considered suitable for cultivation under sodic soil conditions. Soil application of gypsum@ $4.8 \mathrm{t} \mathrm{ha}^{-1}$ mitigated the ill effects of sodicity and thus enhanced both germination and subsequent plant growth.

\section{LITERATURE CITED}

Abrol I P and Bhumbla D R. 1971. Saline and sodic soils of India-their occurrence and managements. Report of regional seminar on soil survey and soil fertility research in Asia and Far east. FAO Rome. pp 42-57.

Akthar S, Abdul Wahid, Akram M and Ejaz R. 2001. Some growth, photosynthetic and anatomical attributes of sugarcane genotyped under $\mathrm{NaCl}$ salinity. International Journal of Agricultural Biology 3(4): 439-443.

Ashraf M, Mc-Neilly T and Bradshaw A D. 1986. Heritability of nacl tolerance at the seedling stage in seven grass sesis. Crop Sciences 27: 232-234.

Epstein E and Rains D W. 1987. Advances in salt tolerance. Plant and Soil 99: 17-29.

Geetha S, Backiyavathi M R and Wilfred M W. 2000. A promising sugarcane variety for alkaline soil of Cauvery Delta zone. Madras Agricultural Journal 87: 4-6.

Gomathi R and Dhandapani T. 2005. Impact of salt stress on sett germination and subsequent seedling growth of sugarcane, influence of $\mathrm{GA}_{3}$ on imparting salt tolerance. Indian Sugar 113-119.

Gosnell J M. 1972. Some effects of water table level on the growth of sugarcane. Proceedings of $14^{\text {th }}$ Cong, ISS CT. 841-849.

Kumaraswamy K. 1989. Evaluation soil management most important to get better yield. Kissan World 12: 20-22.

Mahamed-Haroon A R, Subash M, Chandrabose K, Shanmugam K, Rajukannu and Manickam T S. 1996. Reclamation of alkali soils. Tamil Nadu experience, Anbil Dharmalingam Agricultural College and Research Institute, Navallure Kuttapatu, Tiruchirapalli.

Muniaswamy. 1998. Growth and development of sugarcane varieties in saline environment. M. Sc. (Agriculture) Thesis, submitted in Tamil Nadu Agricultural University Coimbatore and in collaboration with Sugarcane Breeding Institute, Coimbatore, Tamil Nadu.

Reddy M S. 1980. Effect of salinity and alkalinity on sugarcane to determine the optimum salt concentration for screening sugarcane varieties. Annual Report Sugarcane Breeding Institute. pp 71.

Robinson F E and Worker G F. 1965. Growth of sugarcane in areas irrigated with Colorado river water. California Aric 19 (8): $2-3$.

Tiwari T N, Singh S K, Sharma S, Singh R R, Singh D N and Singh S B. 2006. Performance of sugarcane varieties under sodic soil. Cooperative Sugar 37: 45-49. 